\title{
РОЛЬ ПРОЦЕСІВ ПЕРОКСИДНОГО ОКИСНЕННЯ ЛІПІДІВ I АНТИОКСИДАНТНОЇ СИСТЕМИ В МІОКАРДІ В ПАТОГЕНЕЗІ ФОРМУВАННЯ АДРЕНАЛІНОВОГО УШКОДЖЕННЯ МІОКАРДА
}

Вступ. Серцево-судинна патологія залишається актуальною проблемою сьогодення як одна з основних причин смертності та інвалідності людей працездатного віку. Зокрема, в останні десятиліття особливу увагу приділяють одному з важливих молекулярних механізмів ушкодження клітин, що охоплює процеси пероксидного окиснення ліпідів і антиоксидантну систему при адреналіновому ушкодженні міокарда (АУМ).

Мета дослідження - з'ясувати особливості зміни маркерів пероксидного окиснення ліпідів і антиоксидантної системи в міокарді в динаміці розвитку адреналінового ушкодження міокарда.

Методи дослідження. Досліди проведено на 45 білих щурах-самцях, яких поділили на 5 груп (по 9 тварин у кожній): 1-ша - контрольна; 2-га, 3-тя, 4-та, 5-та - тварини з АУМ, відповідно, на 1-шу, 7-му, 10-ту і 17-ту доби експерименту. Визначали вміст дієнових кон'югатів, малонового діальдегіду, церулоплазміну та активність супероксиддисмутази, каталази.

Результати й обговорення. За результатами біохімічних досліджень, на 1-шу, 7-му, 10-ту і 17-mу доби фрормування АУМ спостерігали зростання вмісту в міокарді дієнових кон'югатів. Визначення в міокарді іншого показника пероксидного окиснення ліпідів - малонового діальдегіду показало аналогічний напрямок порушень. Встановлено, що на 1-шу добу активність супероксиддисмутази зростала, на 7-му не зазнавала змін, на 10-ту і 17-ту - знижувалась. Аналогічно змінювалась активність каталази і церулоплазміну. Отже, при дослідженні показників прооксидантно-антиоксидантної системи в міокарді спостерігали постійне нагромадження продуктів ліпопероксидації на тлі виснаження як ензимних, так і неензимних ланок антиоксидантної системи в міокарді, що свідчило про порушення рівноваги між пероксидним окисненням ліпідів і антиоксидантною системою.

Висновок. Визначення маркерів вільнорадикального окиснення (дієнових кон'югатів, малонового діальдегіду) та антиоксидантної системи (супероксиддисмутази, каталази, церулоплазміну) в міокарді показало поступову стимуляцію процесів пероксидного окиснення ліпідів і компенсаторне підвищення активності досліджуваних ензимів із наступною депресією антиоксидантного захисту, особливо на 10-ту і 17-ту доби фрормування адреналінового ушкодження міокарда.

КЛЮЧОВІ СЛОВА: адреналінове ушкодження міокарда; пероксидне окиснення ліпідів; антиоксидантна система.

ВСТУП. Серцево-судинна патологія залишається актуальною проблемою сьогодення як одна з основних причин смертності та інвалідності людей працездатного віку. Згідно з даними вОО3, смертність від цієї патології в нашій країні становить понад $50 \%$. За показниками захворюваності більшість становлять чоловіки, проте смертність вища в жіночій когорті, особливо в осіб похилого віку [1]. Однією з причин розвитку серцево-судинної патології $€$ інораркт міокарда, коли кардіоміоцити гинуть внаслідок тривалої ішемії. Інфраркт міокарда - динамічний процес, який супроводжується переходом оборотних змін до незворотного ішемічного ушкодження і ( ) М. С. Регеда, О. Т. Городецький, 2019. завершується заміною змертвілої частини міокарда фріброзним рубцем. Розвиток фріброзу $\epsilon$ також динамічним процесом, в якому міофрібробласти, головні клітинні елементи фріброзу, не тільки метаболічно активні й здатні до вироблення та позитивної регуляції цитокінів, але й мають скоротливі властивості, що допомагає хворим із серцевою недостатністю [2]. Зокрема, в останні десятиліття особливу увагу приділяють одному з важливих молекулярних механізмів ушкодження клітин, що охоплює процеси пероксидного окиснення ліпідів і антиоксидантну систему при адреналіновому ушкодженні міокарда (АУМ).

Мета дослідження - з'ясувати особливості зміни маркерів пероксидного окиснення ліпідів і 
антиоксидантної системи в міокарді в динаміці розвитку адреналінового ушкодження міокарда.

МЕТОДИ ДОСЛІДЖЕННЯ. Досліди проведено на 45 нелінійних білих щурах-самцях масою 0,17-0,21 кг, яких поділили на 5 груп (по 9 тварин у кожній): 1-ша - контрольна (інтактна); 2-га, 3-тя, 4-та, 5-та - тварини з АУМ, відповідно, на 1-шу, 7-му, 10-ту і 17-ту доби експерименту. Гостре адреналінове ушкодження міокарда моделювали шляхом одноразового внутрішньочеревного введення 0,18 \% адреналіну гідротартрату ("Дарниця", Україна) з розрахунку 1 мг/кг за методом О. О. Маркової [3]. Тварин з АУМ виводили $з$ експерименту на 1-шу, 7-му, 10-ту і 17-ту доби його розвитку під налбусріновим наркозом внутрішньочеревно в дозі 182 мг/кг маси тіла щура і забирали тканини міокарда для біохімічних досліджень. Експерименти було проведено згідно з принципами біоетики відповідно до положень Європейської конвенції про захист хребетних тварин, що використовуються для дослідних та інших наукових цілей (Страсбург, 1986), Директиви Ради Європи 2010/63/EU, Закону України № 3447-IV "Про захист тварин від жорстокого поводження", загальних етичних принципів експериментів на тваринах, ухвалених на Першому національному конгресі України 3 біоетики Львівського національного медичного університету імені Данила Галицького (протокол від 18 січня 2017 р. № 4). Вміст дієнових кон'югатів (ДК) визначали за методом В. Б. Гаврилова [4], малонового діальдегіду (МДА) - за методом Е. Н. Коробейникової [5], активність супероксиддисмутази (СОД) - за методом R. Fried [6], каталази (KT) - за методом R. Holmes [7], вміст церулоплазміну (ЦП) - за методом В. Г. Колб, В. С. Камишникова [8]. Одержані цифррові результати було опрацьовано статистично методом Стьюдента.
РЕЗУЛЬТАТИ Й ОБГОВОРЕННЯ. За реЗУЛЬтатами біохімічних досліджень, на 1-шу, 7-му, 10-ту і 17-ту доби орормування АУМ спостерігали зростання вмісту в міокарді ДК - на 95,0 \% $(p<0,05), 45,9 \%(p<0,05), 44,3 \%(p<0,05), 44,9 \%$ $(p<0,05)$ відповідно проти групи інтактних тварин (рис.). Визначення в міокарді іншого показника пероксидного окиснення ліпідів - МДА показало аналогічний напрямок порушень. Він підвищувався на 88,9\% $(p<0,05), 43,0 \%(p<0,05), 33,6 \%$ $(p<0,05), 34,8 \%(p<0,05)$, відповідно, на 1-шу, 7-му, 10-ту і 17-ту доби АУМ відносно контролю, що свідчило про активацію процесів вільнорадикального окиснення (рис.). Таким чином, дослідження його маркерів у динаміці фрормування кардіоміопатії показало поступову стимуляцію процесів ліпопероксидації. Відомо, що надмірне утворення продуктів пероксидного окиснення ліпідів виснажує антиоксидантну систему. Разом із вивченням порушень прооксидантної системи досліджували особливості змін антиоксидантного захисту за показниками активності супероксиддисмутази, каталази, вмісту церулоплазміну в міокарді у динаміці фрормування АУМ. Встановлено, що на 1-шу добу активність СОД зростала на 45,2 \% (p<0,05), на 7-му - не зазнавала змін, на 10-ту і 17-ту - знижувалась, відповідно, на 51,6 \% $(p<0,05)$ та 68,2 \% $(p<0,05)$ проти 1-ї групи тварин. Аналогічно змінювалась активність КТ: на 1-шу добу - підвищувалась на 47,1 \% ( $<<0,05)$, на 7-му - не відрізнялась від показника контролю, на 10-ту і 17-ту - при кардіоміопатії зменшувалась, відповідно, на 57,3 \% $(p<0,05)$ та 77,1 \% $(p<0,05)$ відносно інтактної групи білих щурів-самців (рис.). Вміст ЦП на 1-шу добу збільшувався на 34,2 \% ( $p<0,05)$, на 7-му не зазнавав змін, на 10-ту і 17-ту - знижувався, відповідно, на 44,7 \% (p<0,05) та 52,6 \% $(p<0,05)$ порівняно з контролем (рис.). Отже, при дослідженні показників прооксидантно-антиоксидант-

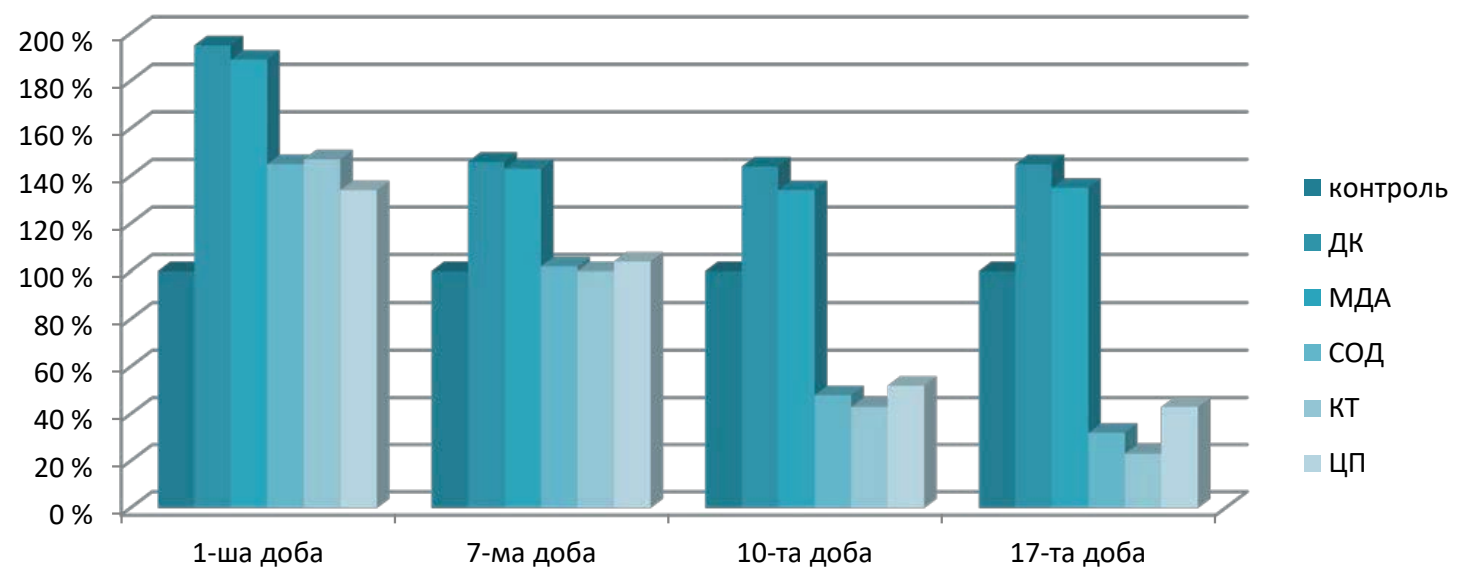

Рис. Рівень продуктів пероксидного окиснення ліпідів і активність ензимів антиоксидантної системи в міокарді при адреналіновому ушкодженні міокарда (\% порівняно з контролем). 
ної системи в міокарді спостерігали постійне нагромадження продуктів ліпопероксидації на тлі виснаження як ензимних, так і неензимних ланок антиоксидантної системи в міокарді, що свідчило про порушення рівноваги між пероксидним окисненням ліпідів та антиоксидантною системою. Отримані результати досліджень вказують на те, що в усі періоди розвитку АУМ за умов депресії антиоксидантної системи активувались процеси вільнорадикального окиснення, які домінували на 10-ту і 17-ту доби експерименту, що свідчило про наявність оксидативного стресу та їх участь у патогенезі фрормування цієї експериментальної моделі хвороби.

\section{СПИСОК ЛІТЕРАТУРИ}

1. Ратманова А. Сердечно-сосудистая заболеваемость и смертность - статистика по европейским странам / А. Ратманова // Medicine Review. - 2009. № 1. - C. 6-12.

2. Мусієнко А. М. Зміни показників кардіоінтервалограсрії при адреналіново-кальцієвій моделі ураження серця у тварин та застосуванні для корекції кверцетину / А. М. Мусієнко // Art of medicine. - 2018. № 3 (7). - C. 96-99.

3. Маркова О. О. Міокардіодистрофія і реактивність організму / О. О. Маркова. - Тернопіль : Укрмедкнига, 1998. - 152 с.

4. Гаврилов В. Б. Спектросротометрическое определение содержания гидроперекисей липидов в плазме крови / В. Б. Гаврилов, М.И.Мишкорудная //

\section{REFERENCES}

1. Ratmanova, A. (2009). Serdechno-sosudistaya zabolevayemost i smertnost - statistika po evropeyskim stranam [Cardiovascular morbidity and mortality statistics on European countries]. Medicine Review, 1, 06-12 [in Russian].

2. Musiienko, A.M. (2018). Zminy pokaznykiv kardiointervalografii pry adrenalinovo-kaltsiievii modeli urazhennia sertsia u tvaryn ta zastosuvanni dlia korektsii kvertsetynu [Changes of cardiointervalography indexes in adrenalin-calcium heart damage models in animals and application for quercetin correction]. Art of Medicine, 3 (7), 96-99 [in Ukrainian].

3. Markova, O.O. (1998). Miokardiodystrofiia i reaktyvnist orhanizmu [Myocardial dystrophy and reactivity of the body]. Ternopil: Ukrmedknyha [in Ukrainian].

4. Gavrilov, V.B., \& Mishkorudnaya, M.I. (1989). Spektrofotometricheskoye opredeleniye soderzhaniya gidroperekisey lipidov v plazme krovi. Laboratornaya
ВИСНОВКИ. Визначення маркерів вільнорадикального окиснення (дієнових кон'югатів, малонового діальдегіду) та антиоксидантної системи (супероксиддисмутази, каталази, церулоплазміну) в міокарді показало поступову стимуляцію процесів пероксидного окиснення ліпідів і компенсаторне підвищення активності досліджуваних ензимів із наступною депресією антиоксидантного захисту, особливо на 10-ту і 17-ту доби фрормування адреналінового ушкодження міокарда, що вказує на розвиток оксидативного стресу, який, на нашу думку, очевидно, посилює фрормування некротичних процесів у міокарді.

Лабораторная диагностика ишемической болезни сердца. - К. : Здоров'я, 1989. - С. 170-171.

5. Коробейникова Э. Н. Модификация определения продуктов ПОЛ в реакции с тиобарбитуровой кислотой / Э. Н. Коробейникова // Лаб. дело. - 1989. № 7. - C. 8-10.

6. Fried R. Enzymatic and non-enzymatic assay of superoxideifilii / R. Fried // Biochemie. - 1975. - 57, No. 5. - P. 657-660.

7. Holmes R. Epigenetic interconversions of the multiple forms of mouse liver catalase / R. Holmes, C. Masters // FEBS Lett. - 1970. - 11, No. 11. - P. 45-48.

8. Колб В. Г. Определение активности церулоплазмина в крови : справочник по клинич. химии / В. Г. Колб, В. С. Камышников. - Минск : Беларусь, 1982. - C. 290-291.

diagnostika ishemicheskoy bolezni serdtsa [Spectrophotometric determination of the content of lipid hydroperoxides in blood plasma. Laboratory diagnosis of coronary heart disease]. Kyiv: Zdorovia [in Russian].

5. Korobeynikova, Ye.N. (1989). Modifikatsiya opredeleniya produktov POL v reaktsii s tiobarbiturovoy kislotoy [Modification of the definition of the products of the LPO in reaction with thiobarbituric acid]. Laboratornoye delo - Laboratory Case, 7, 8-10 [in Russian].

6. Fried, R. (1975). Enzymatic and non-enzymatic assay of superoxideifilii. Biochemie, 57 (5), 657-660.

7. Holmes, R., \& Masters, C. (1970). Epigenetic interconversions of the multiple forms of mouse liver catalase. FEBS Lett, 11 (11), 45-48.

8. Kolb, V.G., \& Kamishnikov, V.S. (1982). Opredelenye aktivnosti tsereloplazmina $v$ krovi. Spravochnik po klinicheskoy khimii [Determination of the activity of ceraloplasmin in the blood. Reference book on Clinical Chemistry]. Minsk: Belarus [in Russian]. 


\section{РОЛЬ ПРОЦЕССОВ ПЕРЕКИСНОГО ОКИСЛЕНИЯ ЛИПИДОВ \\ И АНТИОКСИДАНТНОЙ СИСТЕМЫ В МИОКАРДЕ В ПАТОГЕНЕЗЕ ФОРМИРОВАНИЯ АДРЕНАЛИНОВОГО ПОВРЕЖДЕНИЯ МИОКАРДА}

\section{Резюме}

Вступление. Сердечно-сосудистая патология остается актуальной проблемой современности как одна из основных причин смертности и инвалидности людей трудоспособного возраста. В частности, в последние десятилетия особое внимание уделяют одному из важных молекулярных механизмов повреждения клеток, что охватывает процессы перекисного окисления липидов и антиоксидантную систему при адреналиновом повреждении миокарда (АПМ).

Цель исследования - выяснить особенности изменения маркеров перекисного окисления липидов и антиоксидантной системы в миокарде в динамике развития адреналинового повреждения миокарда.

Методы исследования. Опыты проведены на 45 белых крысах-самцах, которых разделили на 5 групп (по 9 животных в каждой): 1-я - контрольная; 2-я, 3-я, 4-я, 5-я - животные с АПМ, соответственно, на 1-е, 7-е, 10-е и 17-е сутки эксперимента. Определяли содержание диеновых конъюгатов, малонового диальдегида, церулоплазмина и активность супероксиддисмутазы, каталазы.

Результаты и обсуждение. По результатам биохимических исследований, на 1-е, 7-е, 10-е и 17-е сутки формирования АПМ наблюдали возрастание содержания в миокарде диеновых конъюгатов. Определение в миокарде другого показателя перекисного окисления липидов - малонового диальдегида показало аналогичное направление нарушений. Установлено, что на 1-е сутки активность супероксиддисмутазы возрастала, на 7-е - не изменялась, на 10-е и 17-е-снижалась. Аналогично изменялась активность каталазы и церулоплазмина. Таким образом, при исследовании показателей прооксидантно-антиоксидантной системы в миокарде наблюдали постоянное накопление продуктов липопероксидации на фроне истощения как энзимных, так и неэнзимных звеньев антиоксидантной системы в миокарде, что свидетельствовало о нарушении равновесия между перекисным окислением липидов и антиоксидантной системой.

Вывод. Определение маркеров свободнорадикального окисления (диеновых конъюгатов, малонового диальдегида) и антиоксидантной системы (супероксиддисмутазы, каталазы, церулоплазмина) в миокарде показало постепенную стимуляцию процессов перекисного окисления липидов и компенсаторное повышение активности исследуемых энзимов с последующей депрессией антиоксидантной защиты, особенно на 10-е и 17-е сутки фрормирования адреналинового повреждения миокарда.

КЛЮЧЕВЫЕ СЛОВА: адреналиновое повреждение миокарда; перекисное окисление липидов; антиоксидантная система.

M. S. Regeda, O. T. Horodetskyy DANYLO HALYTSKYI LVIV NATIONAL MEDICAL UNIVERSITY

\section{THE ROLE OF LIPID PEROXIDATION PROCESSES AND ANTIOXIDANT SYSTEM IN MYOCARDIUM IN PATHOGENESIS OF FORMATION OF ADRENALINE MYOCARDIAL INJURY}

\section{Summary}

Introduction. Cardiovascular pathology remains an actual problem of the present, as one of the main causes of mortality and disability of people of working age. In particular, over the past decades, particular attention has been paid to one of the important molecular mechanisms of cell damage that involves lipid peroxidation and antioxidant system during adrenal myocardium injury (AMI).

The aim of the study - to elucidate the changes in the markers of lipid peroxidation and antioxidant system in the myocardium in the dynamics of adrenal myocardium injury.

Research Methods. Experiments were conducted on 45 white male rats, which were divided into five groups (9 animals in each). Group 1 - control, groups 2, 3, 4, 5-groups of animals with AMI, respectively, in the 1-st, 7-th, 
10-th and 17-th days of the experiment. The content of diene conjugates, malonic dialdehyde, superoxide dismutase, catalase, ceruloplasmin were determined.

Results and Discussion. The results of biochemical studies revealed that the growth of myocardial contents of diene conjugates was observed in the 1-st, 7-th, 10-th and 17-th days of the formation of adrenal damage of the myocardium. Determination of another indicator of lipid peroxidation - malondialdehyde in the myocardium showed a similar trend of disturbances. It was established that at day 1 the activity of superoxide dismutase increases, does not change for the 7-th day, and then decreases by the 10-th and 17-th days. Similar changes are observed with the activity of catalase and ceruloplasmin. Thus, the study of the parameters of the prooxidant antioxidant system in the myocardium showed a constant accumulation of products of lipoperoxidation against the background of exhaustion of both enzymatic and non-fermentative parts of the antioxidant system in the myocardium, indicating an imbalance between the lipid peroxidation and the antioxidant system.

Conclusion. Determination of the markers of free radical oxidation - diene conjugates and malonic dialdehyde and antioxidant system - superoxide dismutase, catalase, ceruloplasmin in the myocardium showed a gradual stimulation of lipid peroxidation processes and compensatory growth of the activity of the enzymes under study, followed by depression of antioxidant defense, especially on the 10-th and 17-th days of adrenal myocardium injury formation.

KEY WORDS: adrenal myocardial injury; lipid peroxidation; antioxidant system.

Отримано 04.01.19

Адреса для листування: О. Т. Городецький, Львівський національний медичний університет імені Данила Галицького, вул. Пекарська, 69, Львів, 79010, Україна, e-mail: oleh@profident-plus.Iviv.ua. 